\title{
SOME NOTES ON THE HADRIANEUM RELIEFS
}

\author{
LAJOS JUHÁSZ
}

\author{
Department of Classical and Roman Archaeology, Institute of Archaeological Sciences \\ Eötvös Loránd University Budapest \\ 4/B Múzeum krt., H-1088 Budapest, Hungary \\ jlajos3@gmail.com
}

\begin{abstract}
The reliefs of the Hadrianeum in Rome still pose a lot of difficulties even several centuries after their discovery. This meant a number of varying identification proposals from different scholars. Some of them are too fragmentary to ever to be solved, but in this paper I propose some modifications to the previous readings based on iconographic parallels.
\end{abstract}

Keywords: Hadrianeum, iconography, coins, reliefs, identification, Rome

The Hadrianeum i.e. the temple of the deified Hadrian was decorated with a series of very interesting, but also very problematic reliefs. A great number of attributes now lost, but once existing has led to several different and often unsubstantiated interpretations. ${ }^{1}$ Because of the two coin series, Hadrian's province and Antoninus Pius' aurum coronarium, it is likely that the reliefs show provinces or other parts of the Roman Empire, or maybe even foreign territories. However, the series are not complete or to be more precise, we do not know according to which system or idea the coin reverses were selected and minted. ${ }^{2}$ So how can we transfer the thought not fully understood to the reliefs, we are not able to identify certainly? The reason for correlating the two is the close proximity in time and the uniqueness of the representations. ${ }^{3}$ The present article would like to propose some new interpretations to some of the reliefs, and add some notes confirming two previous readings, while admitting that most of them cannot be sufficiently identified at present date.

The temple ${ }^{4}$ itself was dedicated by Antoninus Pius in 145 A.D. and was located in the centre of the Campus Martius in Rome, south of the buildings erected by Augustus, on today's Piazza di Pietra (Fig. 1). ${ }^{5}$ North of it ran the via Recta between the via Flaminia and the pons Neronianus. ${ }^{6}$ To the west lay the monuments of Matidia and Marciana erected by Hadrian. The choice of location by Antoninus Pius continued to use the middle of the

${ }^{1}$ LuCAS 1900, 28-42; SAPelli 1999, 28-82; TOYNBeE $1934,155-159$. For a summary of the previous interpretations, see OSTROWSKI 1990, 216-219.

${ }^{2}$ Hadrian's province coins were minted between 134-138 and comprises of 3 different (provincia, adventus, restitutor) series depicting provinces, cities, regions and the Nile. It was most likely a homage to his great journeys across the Empire. There also existed an exercitus series depicting the various Roman troops. Antoninus Pius emitted his smaller aurum coronarium series in 139, where provinces and foreign empires celebrated his accession. RIC II, 838-966; RIC III, 574-596; TOYNBEE 1934, 24-147; STRACK 1933, 139-166; ZAHNRT 2007, 195-212; Vitale 2012, 156-174; HoughtALIN 1996, 504-507.
${ }^{3}$ The concentration of the personifications of geographical territories in imperial art in the first half of the $2^{\text {nd }}$ c. A.D. is also in connection with that Trajan and Hadrian were themselves born in the provinces and not Italy.

${ }^{4}$ SHA Pius 8,2; SAPELli 1999, 12-23; ToynBeE 1934 , 152-159; LiVERANI 1995, 229-233; LuCAS 1900, 1-28; PAIS 1979, 3-4, 11-35; OstrowsKi 1990, 216-219.

${ }^{5}$ The temple was previously identified as the Neptune basilica renovated by Hadrian. PAPI 2005, 52; SHA Hadrian 19,10; PARISI PRESICCE 2005, 76-77. For the construction works of Hadrian See BIRLEY 1997, 111.

${ }^{6}$ BoATWRight 2010, 171-172. 


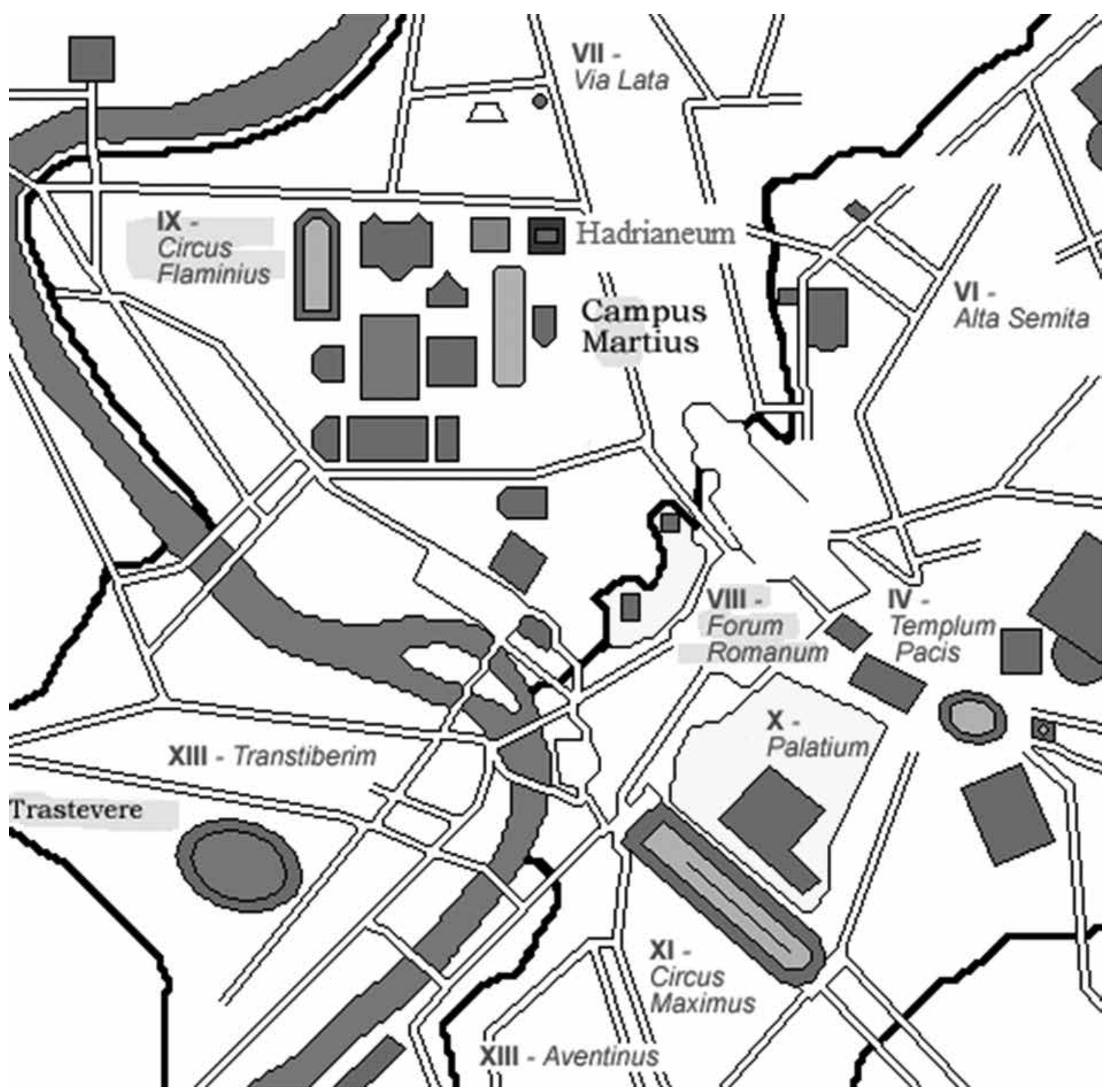

Fig. 1. Map of the ancient Campus Martius with the Hadrianeum (Modified by the author - original from Joris https://commons.wikimedia.org/wiki/File:Plan_Rome-_Tempel_van_Hadrianus.png)

Campus Martius as a place of dynastic representation. Hadrian's deification was not easy to pass through in the Senate, so probably the erection of his temple was also not without hurdles, especially at this location. ${ }^{7}$

The Hadrianeum was a peripteros temple oriented towards east with $8 \times 13$ columns. ${ }^{8} 11$ of these on the north side are still standing decorating the building of the Camera di Commercio, Industria, Artigianato e Agricoltura di Roma (Fig. 2). The edifice stood on a $90 \times 100 \mathrm{~m}$ square surrounded by portico, thus forming a delimited space around the place of worship. Its north part housed an exedra also serving judicial purposes. ${ }^{9}$ The portico was

${ }^{7}$ The relationship between Hadrian and the Senate was quite poor in his last years. PAPI 2005, 52-54.

${ }^{8}$ The building housed the stock exchange from 1870 . SAPElli 1999, 13-14; PARISI PresicCe 2005, 78-82.
${ }^{9}$ For the exedra as a judicial building, see PARISI PRESICCE 2005, 96-98. 


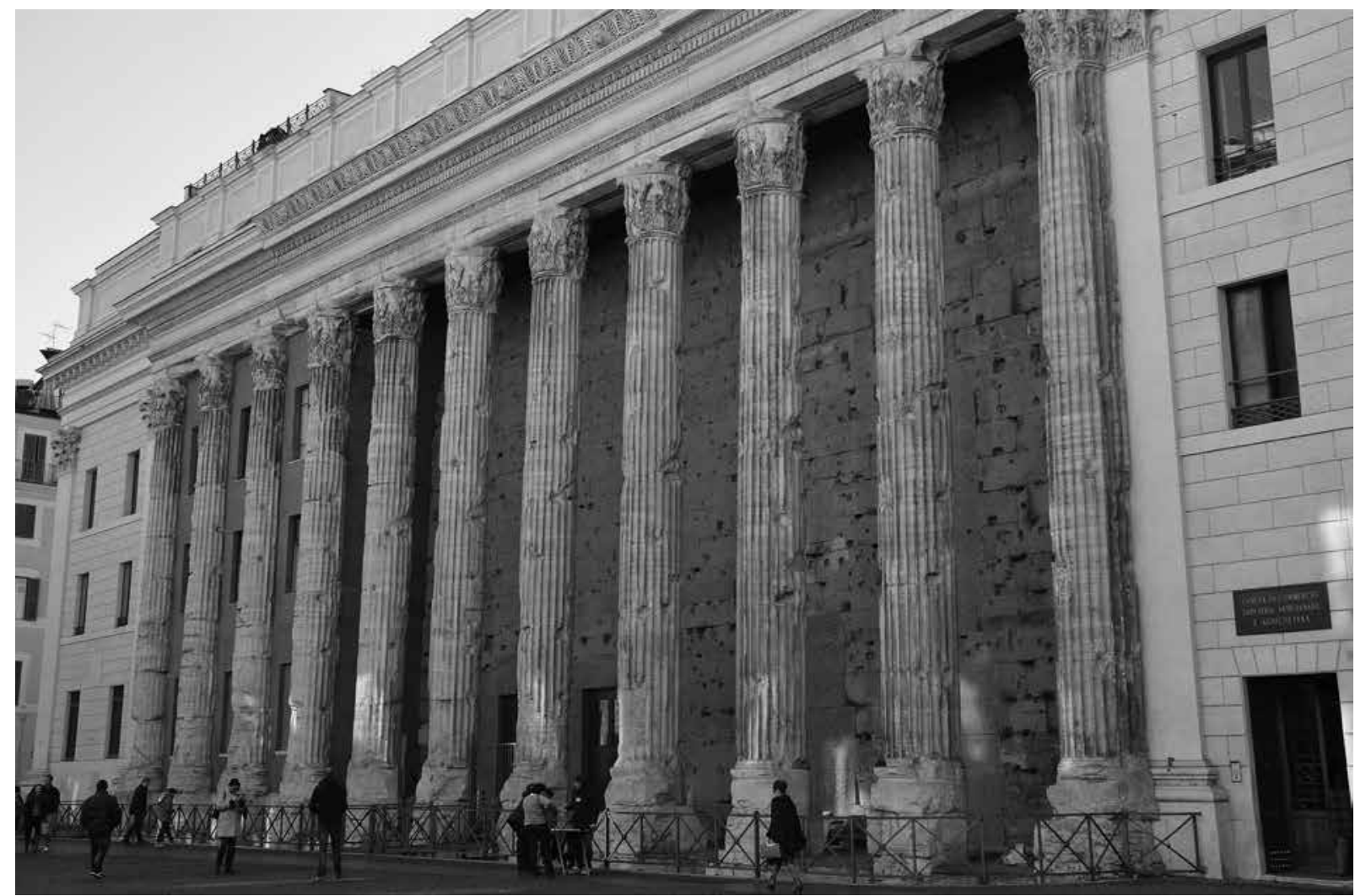

Fig. 2. The Hadrianeum today (FollowingHadrian - https://en.wikipedia.org/wiki/Temple_of_Hadrian\#/media/File:Temple_of_Hadrian.jpg)

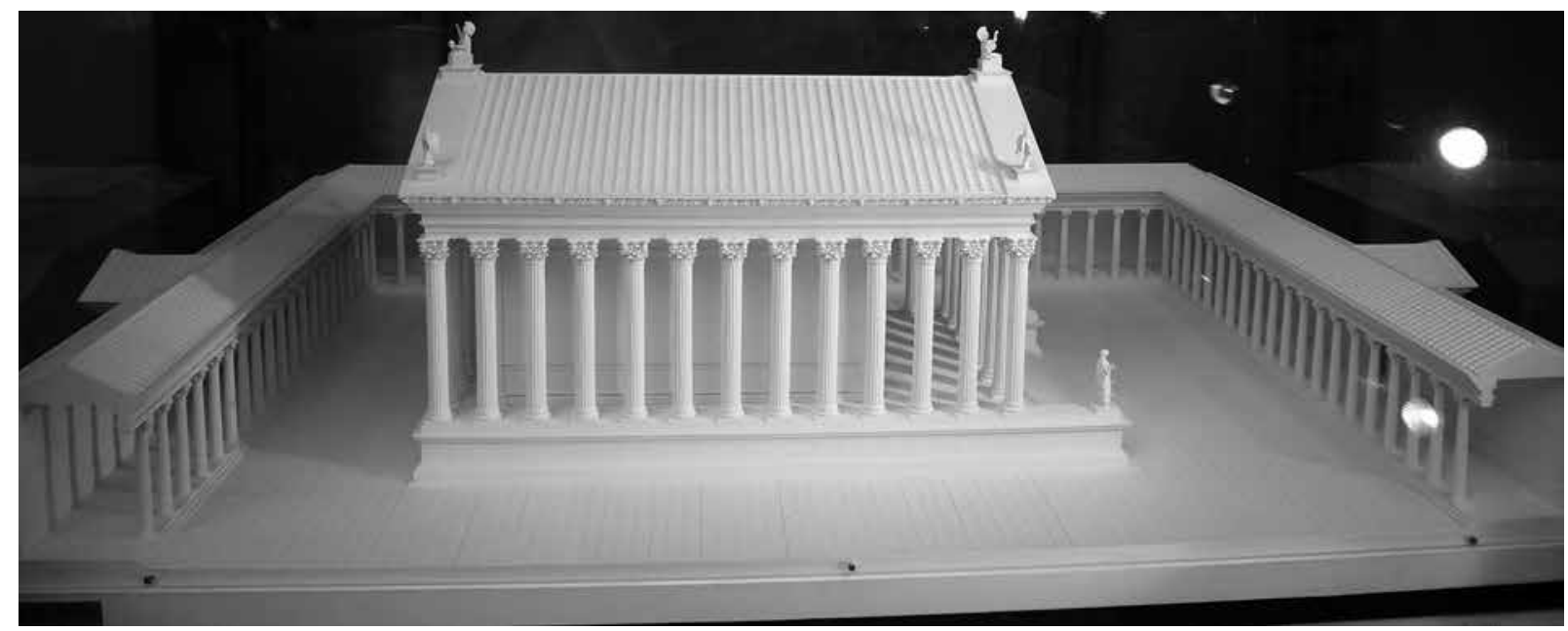

Fig. 3. Reconstruction of the Hadrianeum with portico

(Lalupa - https://en.wikipedia.org/wiki/Temple_of_Hadrian\#/media/File:Colonna_-_Tempio_di_Adriano_ricostruzione_1000165.JPG)

lower than the temple so the Hadrianeum dominated the whole complex with its height (Fig. 3). This can be understood allegorically as Hadrian having been the head of the Roman Empire in his lifetime, following his death became its divine ruler. ${ }^{10}$ An arch stood at the eastern part of the portico by the via Flaminia, which was destroyed before 1527 so its connection to the Hadrianeum is unclear. ${ }^{11}$ 


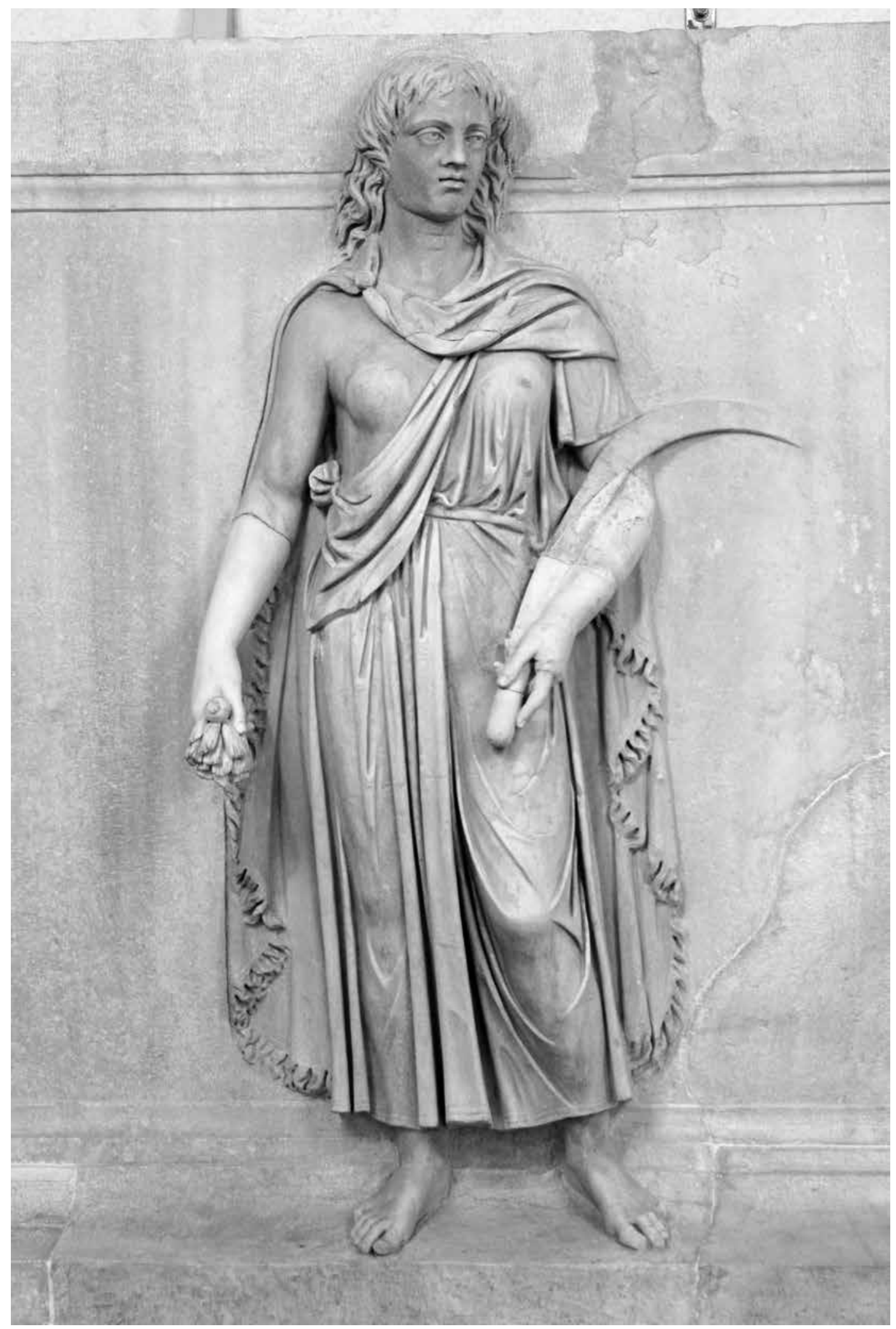

Fig. 4. Dacia on the Hadrianeum (Miguel Hermoso Cuesta

https://it.wikipedia.org/wiki/Tempio_di_Adriano\#/media/File:Hadrianeum_Tracia.JPG) 


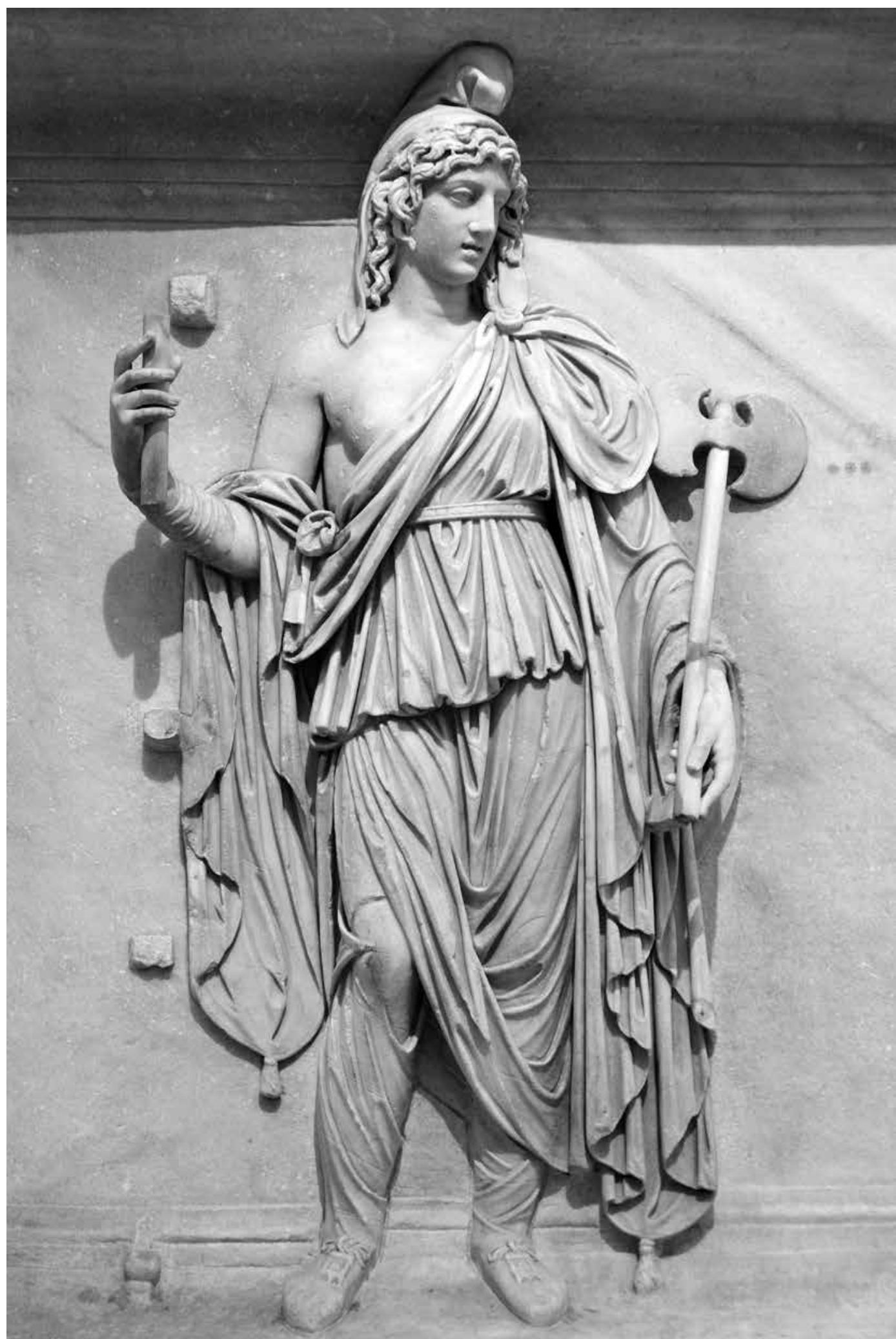

Fig. 5. Phrygia on the Hadrianeum

(Marie-Lan Nguyen - https://it.wikipedia.org/wiki/Tempio_di_Adriano\#/media/File:Bithynia_Hadrianeum_MAN_Napoli_Inv79_n01.jpg) Acta Archaeologica Academiae Scientiarum Hungaricae 69, 2018 


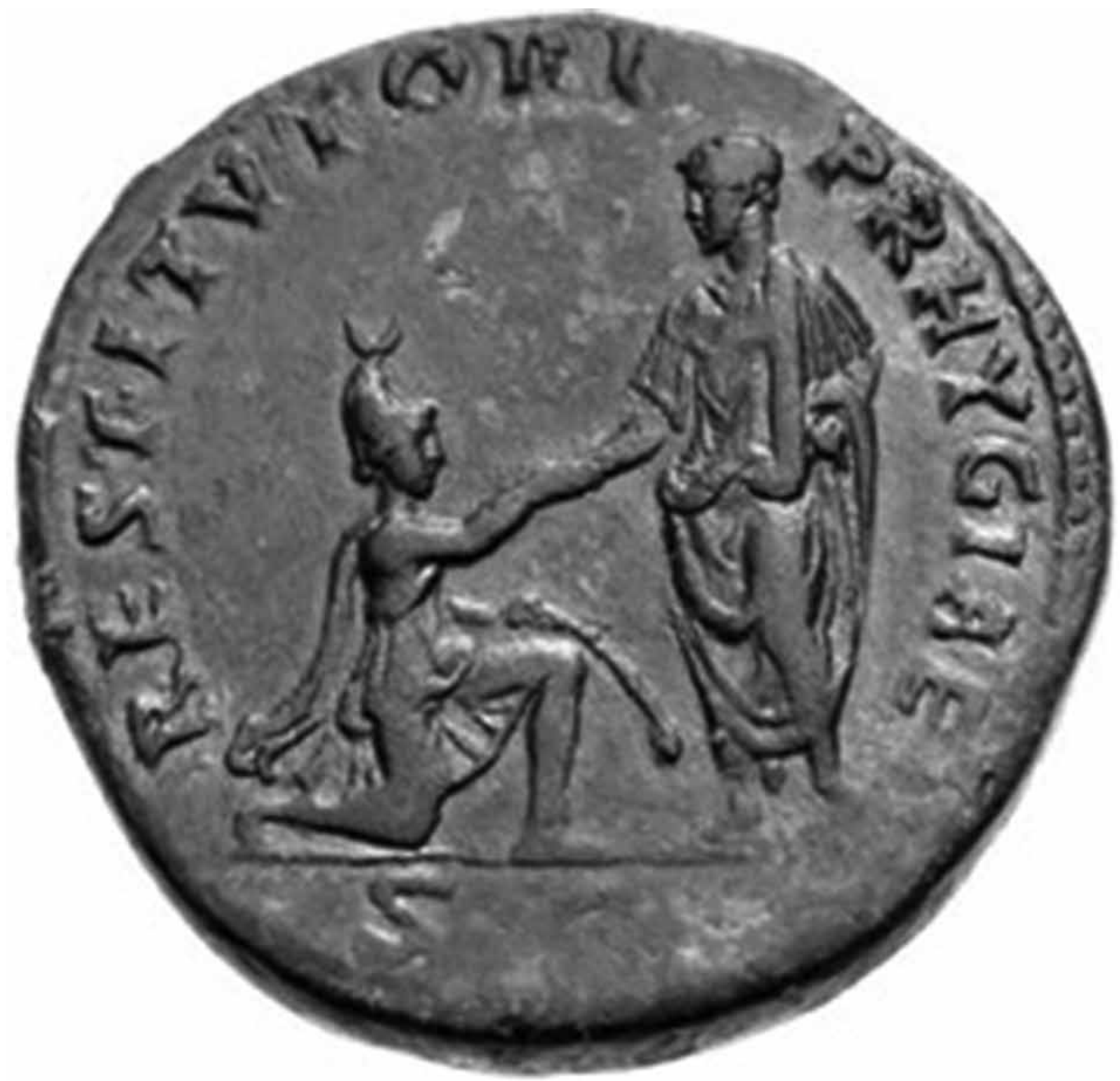

Fig. 6. Phrygia on the coin of Hadrian 134-138 A.D. (Classical Numismatic Group, Inc. http://www.cngcoins. - 12/01/2014 Lot 950)

The most intriguing parts of the Hadrianeum are undoubtedly its sculptural decorations that came to light from the $16^{\text {th }} \mathrm{c}$. onwards at various times. ${ }^{12}$ Until today 25 reliefs survived: 18 female personifications and 7 depicting only weapons and tropaea. ${ }^{13} 3$ others are only known to us via illustrations. It has long been debated which part of the temple the slabs decorated, but today the most likely emplacement seems to be on the attic of the surrounding

${ }^{12}$ This accounts for why the reliefs are now scattered in various Italian collections. Musei Capitolini-Palazzo dei Conservatori (8 pieces), Museo Archeologico Nazionale Napoli (3 pieces), Palazzo Massimo alle Terme (2 pieces), Villa Doria Pamphilj - Casino del Belrespiro, walled in (2 pieces), Palazzo Farnese (1 piece), Camera di Commercio, Industria, Artigianato e Agricoltura di Roma (1 piece), Musei Vaticani - Museo Gregoriano Profano (1 pieces). For the detailed history of the reliefs' appearance see CLARIDGE 1999, 117-121; PARISI PRESICCE 2005, 78-94; PAIS 1979, 11-27.
${ }^{13}$ The relief walled into the side of the Roman Palazzo Senatorio, depicting the bust of Africa, was previously considered to be a part of the Hadrianeum. However, the reliefs do not show any similarities apart from their theme. SAPELLI 1999, 14-17, 28-82; PAIS 1979, 35-95; PAPI 2005, 64; Dodero 2010, 60-68/13-15; DOMES 2007, Re. 2; SAlcedo 1996, 108; Ostrowski 1990, Africa 27; FRANZONI-TEMPESTA 1992, 23-24; LIVERANI 1995, p. 230. n. 44; MATZ-DuHN III, 3624; BIEŃKOWSKI 1900, 94/61; JATTA 1908, 33/20; SAPELLI 1999, 76/25. 


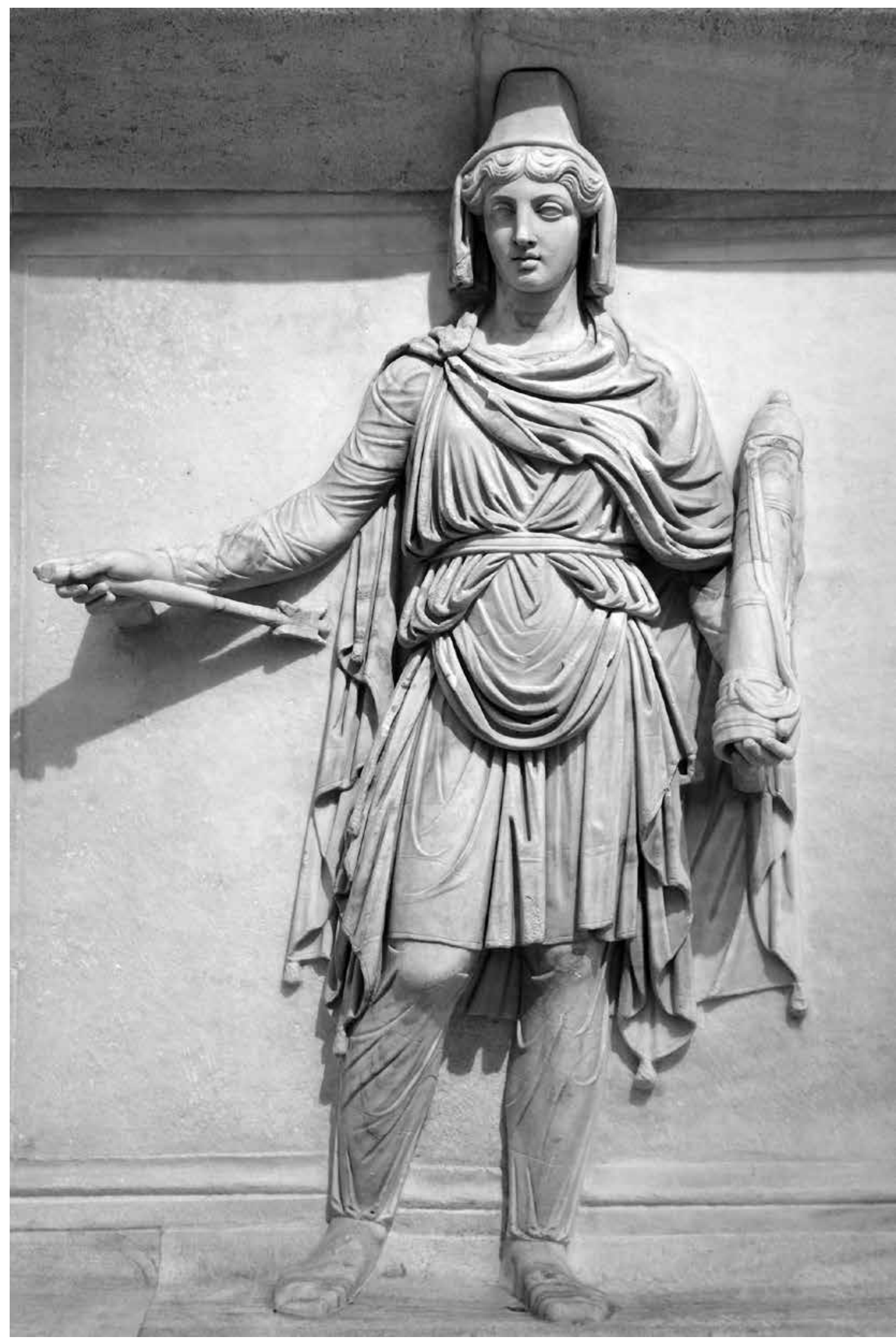

Fig. 7. Relief of Scythia

(Marie-Lan Nguyen - https://it.wikipedia.org/wiki/Tempio_di_Adriano\#/media/File:Armenia_Hadrianeum_MAN_Napoli_Inv79.jpg)

Acta Archaeologica Academiae Scientiarum Hungaricae 69, 2018 


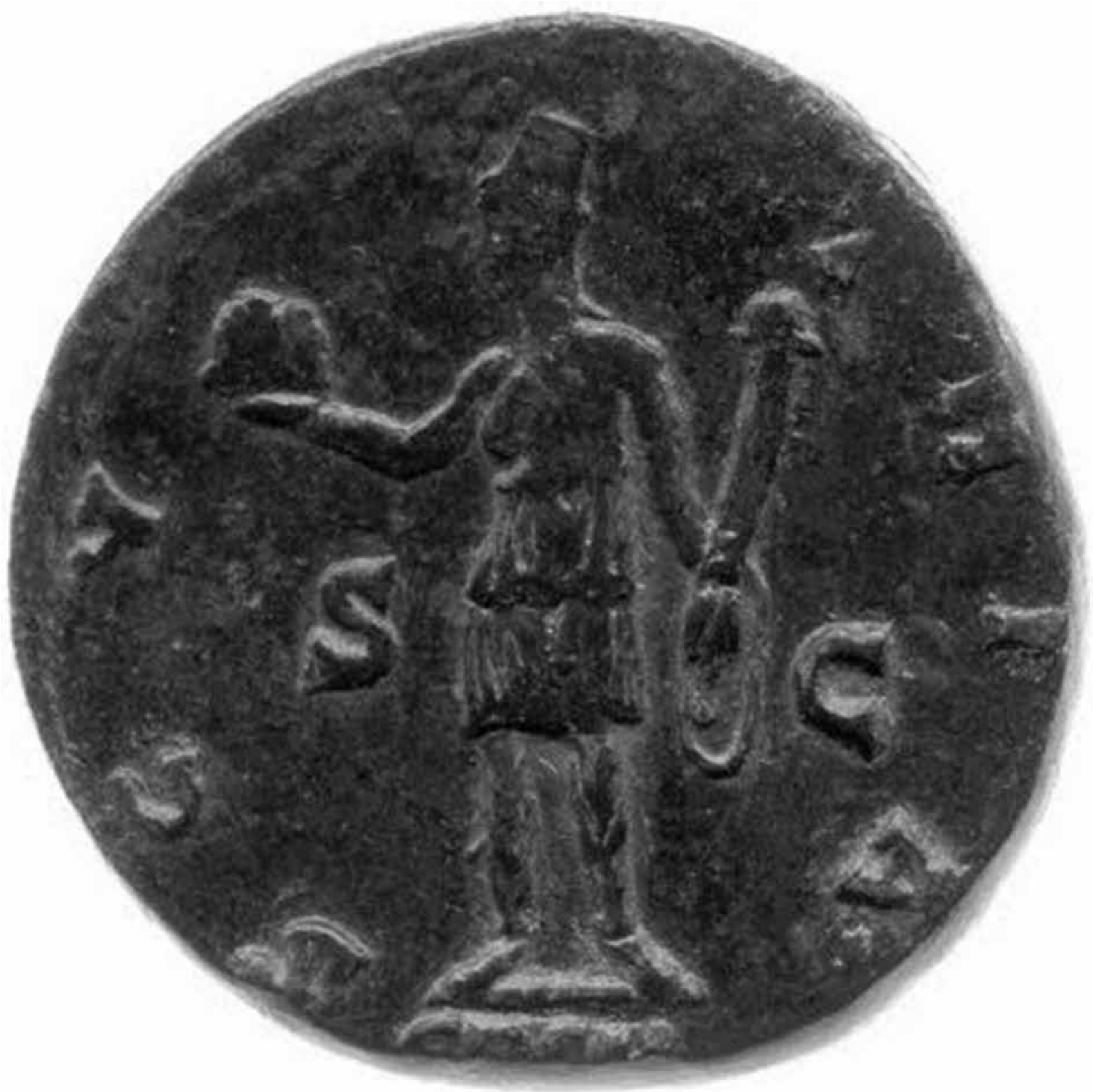

Fig. 8. Scythia on the coin of Antoninus Pius 139. A.D.

(British Museum Collection Database. "RE4p191.1196” www.britishmuseum.org/collection, British Museum. Online. Accessed 29/03/2017)

portico. ${ }^{14}$ The personifications were placed above the columns alternating with the arms between them. This emplacement has parallels on the Forum Transitorium, Forum Traiani or the Sebasteion at Aphrodisias, where the personifications of ethne and provinces decorated these places. ${ }^{15}$

The Hadrianeum relief slabs showing personifications are of a maximum size of $2.08 \times 1.90 \times 0.85 \mathrm{~m}$ from Proconnesian marble, their bottom and top significantly protruding. They all have in common that the female

${ }^{14}$ For a summary of the various interpretations, see Claridge 1999, 121-125; PAPI 2005, 60; PARIsi PREsicCe 2005, 88-94; TOYNBEE 1934, 153-155.
${ }^{15}$ SAPELli 1999, 21-22; SMITH 1988, 50-70; PAPI 2005, 58-62; SEELENTAG 2004, 308-315, 363-366; ÖstENBERG 2009, 29-30. Summarizing the latest excavations' results carried out on the Forum Traiani, see MiLella 2007, 192-211; MENEGHINi 2009, 117-163. 


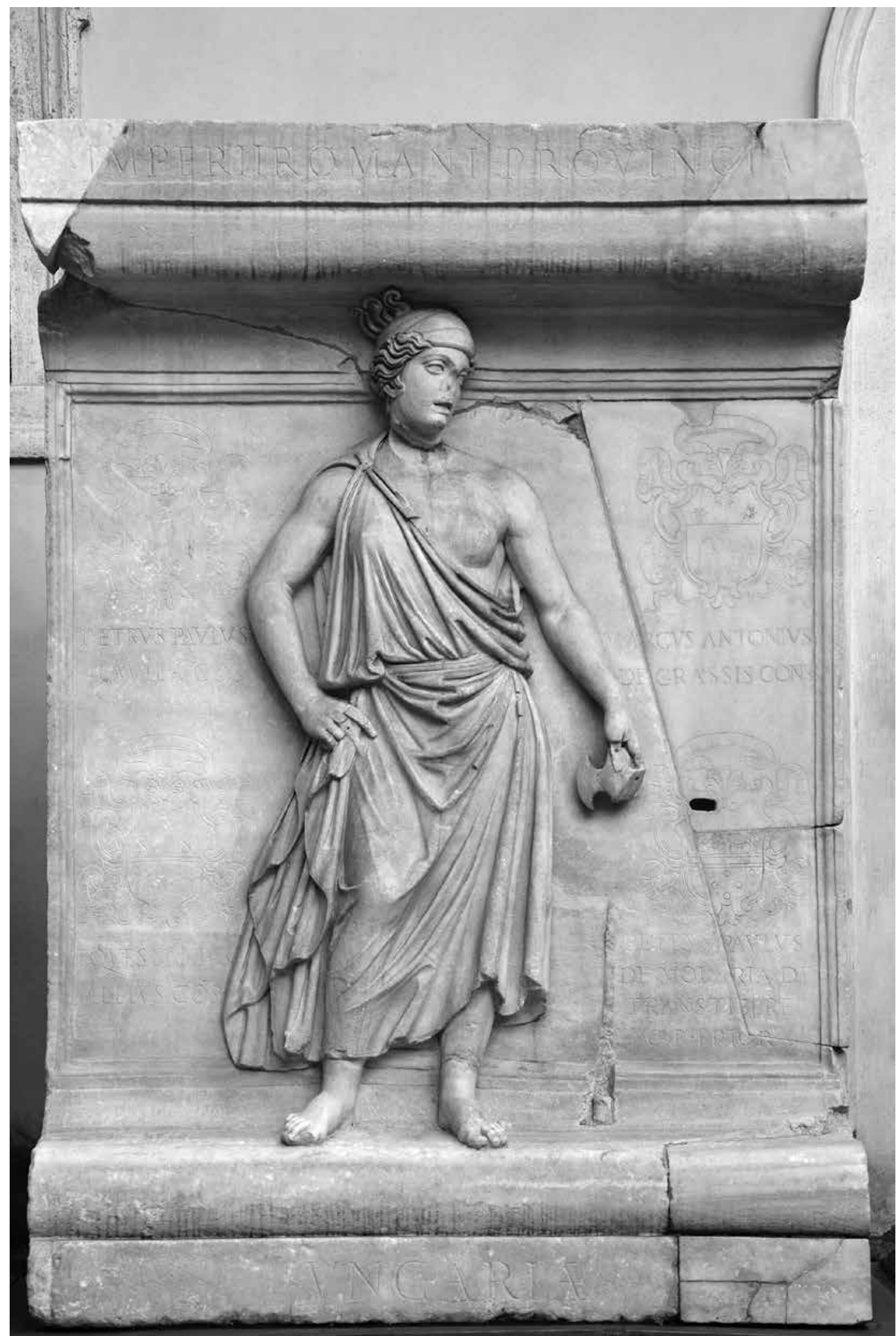

Fig. 9. Bithynia (?) on the Hadrianeum

(Carole Raddato - https://followinghadrian.com/2015/01/21/the-hadrianeum-and-the-personifications-of-provinces/) 


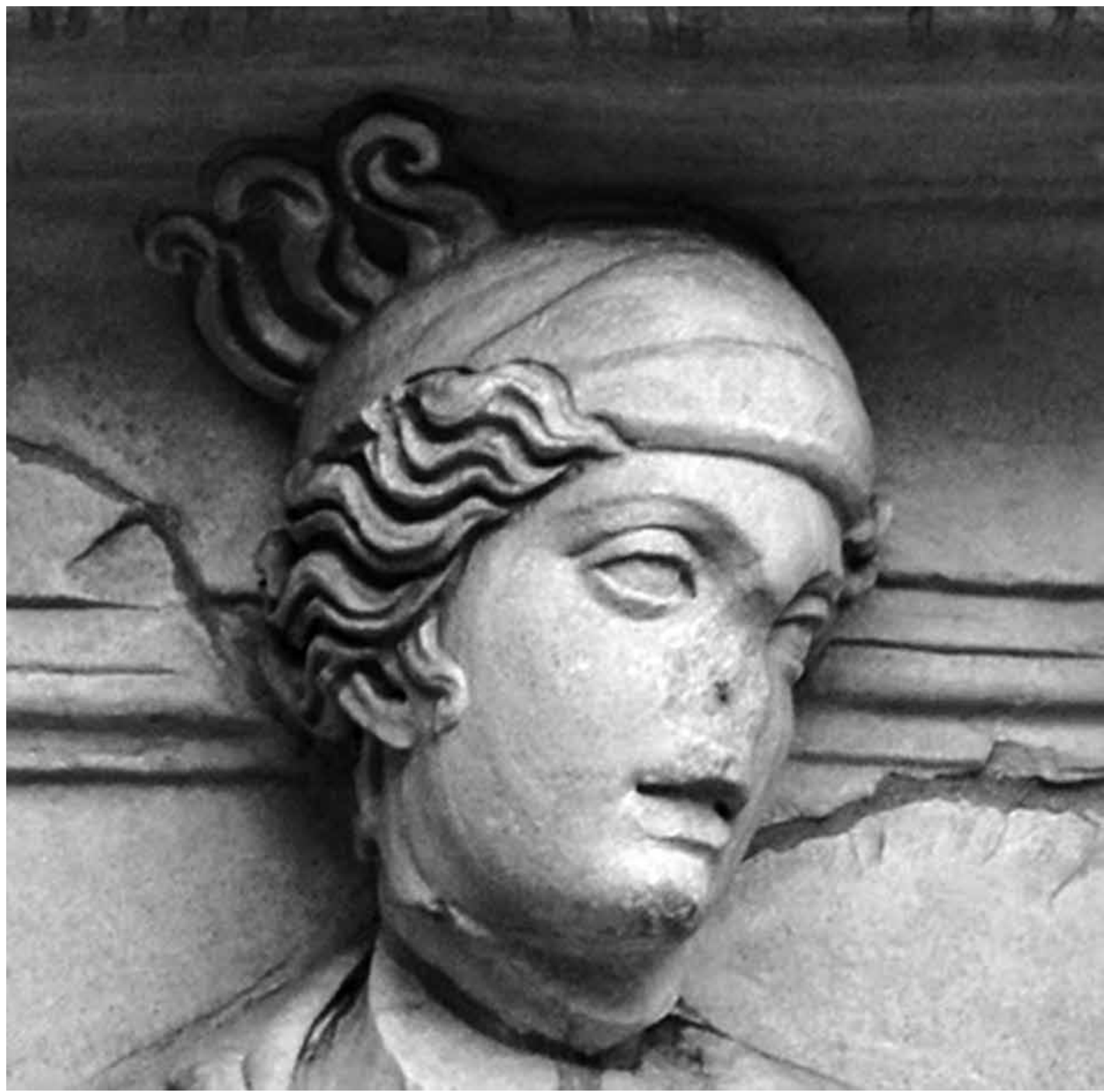

Fig. 10. Detail of the head of Bithynia (?)

figures are facing the viewer, their engaged and free legs changing from slab to slab. ${ }^{16}$ The identification of the figures in high relief set against a polished background are, as mentioned before, very problematic till this day. The biggest difficulty arises from the lack of exact parallel depictions despite Hadrian's and Antoninus Pius' coin series minted few years before. This is further augmented by their fragmentary condition and lack of inscriptions. ${ }^{17}$ Further issues are raised by modern restorations resulting in often completely fictional attributes in the hands of the personifications.

Two reliefs have previously been identified convincingly, so here I only wish to add some supporting remarks. One is in the Palazzo Massimo alle Terme (Inv. 428496) depicting a female figure wearing long tunic leav-

${ }^{16}$ PARISi PResicCe 1999, 96-97.

${ }^{17}$ The Hadrianeum was later used as a quarry, hence the modern Piazza di Pietra name. PAPI 2005, 58. According to Acta Archaeologica Academiae Scientiarum Hungaricae 69, 2018
N. Hannestad's theory the names of the provinces were painted on the reliefs, so that the ancient viewers could identify them. HANNESTAD 1986,198 . 


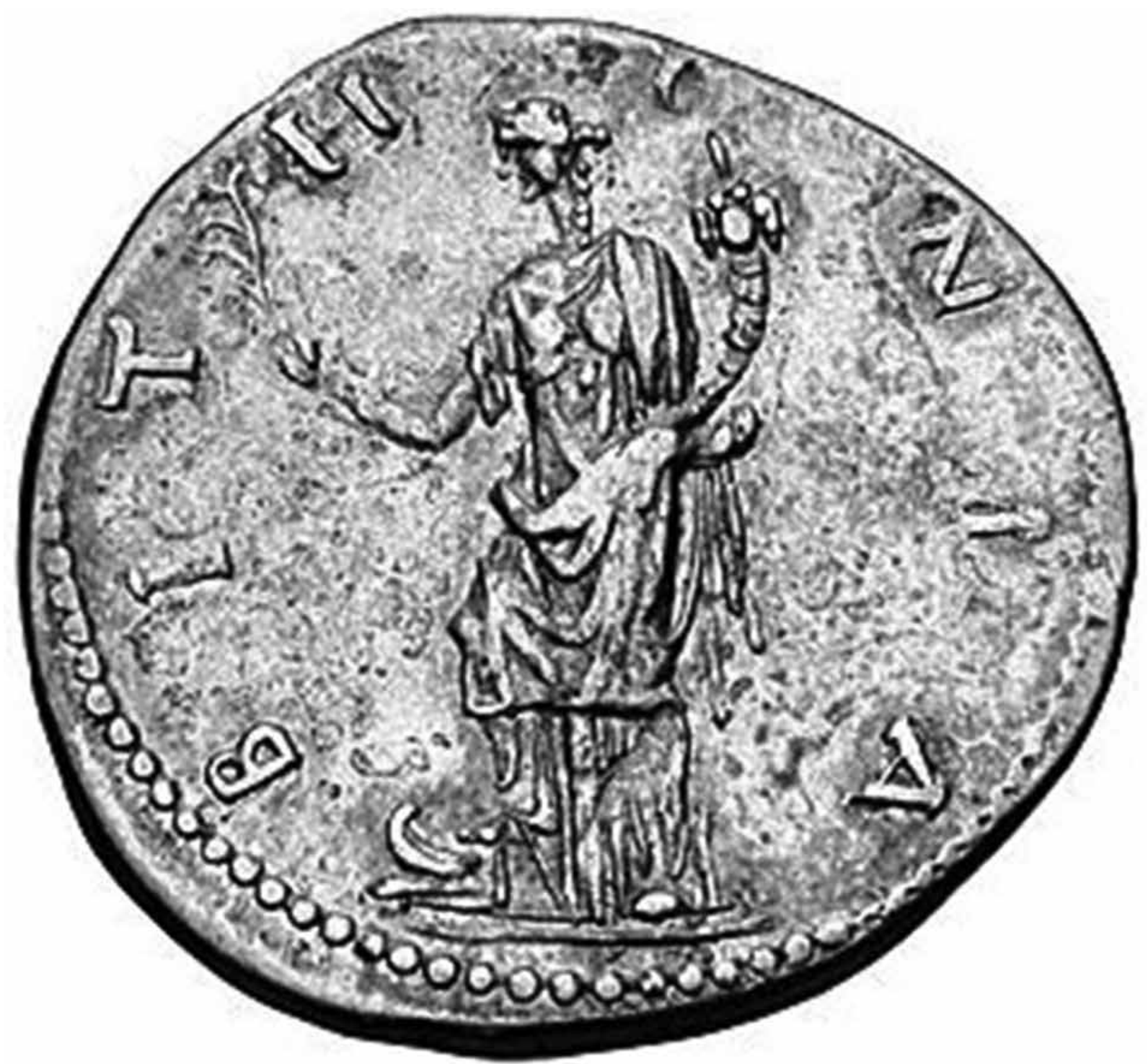

Fig. 11. Bithynia on a locally minted coin of Hadrian (Gemini Auction - Auction II 11/01/2006 Lot 401)

ing one breast bare and fringed cloak, holding sica in her left hand (Fig. 4) ${ }^{18}$ The forearms and the attribute held in the right hand are modern additions. The sica however is valid, because the greater part of it is still preserved at the elbow and on the background. On the basis of this attribute P. Bieńkowski proposed the identification as Dacia, which was accepted amongst others by M. Jatta and J. Ostrowski. ${ }^{19}$ However, J. M. C. Toynbee rejected it seeing rather Thracia represented on the relief, a theory later also accepted by the LIMC. ${ }^{20}$ This has to be refuted, not only on the basis of the sica, but also because of the great resemblance with Antoninus Pius' Dacia coin. ${ }^{21}$ Both are wearing the same kind of tunic leaving one breast bare and mantle, while holding sica in their left hand. The appearance of the latter attribute and the lack of the pileus can be seen in Dacia's iconography since Hadrianic times. ${ }^{22}$

${ }^{18}$ MatZ-Duhn III, 3623; LuCAs 1900, 8-9/F; BIEŃKOWSKI 1900, 68-70/38; STRONG 1907, 389/6; JATTA 1908, 44-45/4; TOYNBEE 1934, 159; Ostrowski 1990, Dacia 23; PAIS 1979, 55-57/8; HoughtALIN 1996, Dacia 38; LIMC Thracia 2; SAPELLI 1999, 48-51/9.
19 BIEŃKOWSKI 1900, 68-70/38; JaTTA 1908, 44-45/4; OSTROWSKI 1990, Dacia 23

\footnotetext{
${ }^{20}$ TOYNBEE 1934,159 ; LIMC Thracia 2.

${ }^{21}$ TOYNBEE $1934,148-149$, Pl. $8 / 3$.

${ }^{22}$ RIC II, 829, 849-850.
}

Acta Archaeologica Academiae Scientiarum Hungaricae 69, 2018 
The other Hadrianeum relief is in Naples depicting a personification wearing short chiton, himation, braccae, shoes and Phrygian cap, holding double axe (Fig. 5). ${ }^{23}$ The end of the long staff held in her right hand is now lost, thus there is no possibility to identify it. The labrys together with the amazon-like appearance point in the direction of Anatolia, while the Phrygian cap identifies the female figure as Phrygia. ${ }^{24}$ This is further supported by Hadrian's restitutor coin where her clothes also go under one shoulder, just like on the relief (Fig. 6). ${ }^{25}$ The attributes held in the hands differ, but this does not necessarily undermine the validity of the interpretation. The pedum can both be seen on the adventus and restitutor coins, but not the labrys. Could thus the lost attribute in the right hand of Phrygia on the relief be a pedum? The length of the staff reaching to the ground suggests otherwise, although some examples show it with a longer shaft.

Of the two newly interpreted reliefs the one kept in Naples (Inv. 6757) depicts a female figure wearing short tunic, mantle, braccae, shoes and an unusual rectangular headgear, while holding arrow and quiver (Fig. 7). ${ }^{26}$ Because the headdress was previously interpreted as a tiara, it was identified with Armenia or Parthia that the weapons would also support. However the braccae, quiver and the strange headdress correspond much closer to Scythia's guise on Antoninus Pius' coin (Fig. 8). This leads me to suggest that the relief does not represent a part of the Roman Empire itself, but rather the foreign territory of Scythia. This is in concordance with Antoninus Pius' aurum coronarium series, where also Parthia is depicted. ${ }^{27}$

The other suggestion put forward here is regarding a relief kept in the Palazzo dei Conservatori (Inv. 761). The female figure is wearing a tunic leaving her left breast bare, holding a labrys in her left hand, while resting the other on her hip (Fig. 9). ${ }^{28}$ Her hair deserves special attention, since the three locks distinctly protruding from under a cap-like headdress and ending in curls are unique (Fig. 10). It resembles an aplustre, which is only found as an attribute of Bithynia. On Hadrianic coins she is twice represented with it. On one restitutor type she is kneeling and holding aplustre, prora before her. ${ }^{29}$ The other is a Bithynian cistophorus on which Bithynia is standing, setting one foot on prora, while holding cornucopia and aplustre (Fig. 11) ${ }^{30}$ The amazon-like attire on the relief, together with the labrys also points to Anatolia, which could strengthen her identification as Bithynia. The aplustre although not a hair decoration, but a symbol of maritime power and victory, is usually held in the hand. In Bithynia's case, it most likely refers to its strategic importance..$^{31}$ It is interesting to note the same iconographic perception reflected on the local provincial as well as the central Roman pieces.

So, as it could be seen the Hadrianeum reliefs can at least to some extent be correlated with Hadrian's and Antoninus Pius' coin series. ${ }^{32}$ However most of them follow a quite different iconography, ones we currently are not able to solve. Despite of its fragmentary survival it seems evident that the Hadrianeum sculptures had a somewhat different ideological background and purpose as the coin series. Unique is e.g. the relief depicting a female figure in cuirass. ${ }^{33}$ Furthermore the personifications are divided by weapons making the Hadrianeum's decoration much more militant. This is surprising since Hadrian gave up the eastern territories conquered by Trajan just before his death and turned the resources to the Empire's consolidation, not expansion. Nonetheless it is important to state that the personifications are not represented in a defeated manner, which corresponds to the coin series. ${ }^{34}$ Antoninus Pius followed Hadrian's peace policy and apart from the early conquest in Britain did not try to expand the

${ }^{23}$ LUCAS 1900, 6-7/C; BIEŃKOWSKI 1900, 66-68/59; Strong 1907, 388-389/3; JATTA 1908, 44/2; ToYNBEE 1934, 158; PAIS 1979, 45-47/3; LIMC Phrygia 3; OsTRowski 1990, Bithynia et Pontus $6=$ Phrygia 7; SAPELLI 1999, 36-37/5; DODERO 2010, 67-68/15.

${ }^{24}$ Christof 2001, 135-145; TyRell 1989, 55-56; LANGER 2007, 31; FLESS 2007, 53.

${ }^{25}$ For the coins see also RIC II 962-964; OsTROwSKI 1990, Phrygia 2; LIMC Phrygia 7; ToynbeE 1934, 127-128; Houghtalin 1996, Phrygia 2; STRACK 1933, 783; SCHMIDT-DiCK 2011, I.6.1.15.

${ }^{26}$ LuCAS 1901, 5-6/B, 36; SAPELli 1999, 32-34/3; PAIS 1979, 42-43/2; ToynbeE 1934, 158-159; Strong 1907, 388/2; OstrowsKi 1990, Armenia 14; DoDero 2010, 65-66/14

${ }^{27}$ RIC III, 586. Interestingly enough this copies Hadrian's Moesia reverse. RIC II, 903.

${ }^{28}$ LUCAS 1901, 9-10/G, 41-42; SAPELLI 1999, 57-58/12; PAIS 1979, 61-63/10; TOYNBEE 1934, 158; BIEŃKOWSKI 1900, 70-
72/39; Strong 1907, 389; JATTA 1908, 45/5; HelbIG II, 1437; OsTROWSKI 1990, 219; LIMC Moesia 19.

${ }^{29}$ RIC II, 947 (the description erroneously describes the aplustre as acrostolium). In other cases she is holding rudder. RIC II, 881, 948-949; ToYnBeE 1934, 51-52; Ostrowski 1990, Bithynia et Pontus 3-4; Houghtalin 1996, Bithynia 5, 7-10; STRACK 1933, 746747, 773-775; LIMC Bithynia 4-6; SCHMIDT-Dick 2011, I.6.10, I.2.04-05, IV.2.07, IV.3.11.

${ }^{30}$ This cistophorus first appeared at an auction in 2006. Gemini Auction II 11/01/2006 Lot 401. Weight 10.55g.

${ }^{31}$ Houghtalin 1996, 134

${ }^{32}$ Cf. PAPI 2005, 64, who states that the Hadrianeum reliefs deliberately escape the possibility of precise identification.

${ }^{33}$ Palazzo dei Conservatori Inv. 767. SAPELLI 1999, 6465/19; PAIS 1979, 69-71/13; ARCE 1980, 89/28; Helbig II, 1437; JATTA 1908, 45/7; BIEŃKOWSKI 1900, 76-78/43; LUCAS 1900, 12/L.

${ }^{34}$ Toynbee 1934, 157; PAPI 2005, 60-62. 
Empire's borders. ${ }^{35}$ This is also reflected by the iconography of the reliefs and the coins, referring to the great journeys of Hadrian and promoting the legitimacy of Antoninus Pius. So, the temple of the Hadrianeum and the portico was a great allegory of the various parts of the Roman Empire and its neighbours surrounding the divine Hadrian in the centre of the ancient world, i.e. Rome. A glorious monument erected for the great predecessor by the pious successor.

\section{REFERENCES}

ARCE 1980

BIEŃKOWSKI 1900

BIRLEY 1997

BOATWRIGHT 2010

CHRISTOF 2001

Claridge 1999

DODERO 2010

DOMES 2007

FLESS 2007

FRANZONI-TEMPESTA 1992

HANNESTAD 1988

HELBIG II

Houghtalin 1996

JATTA 1908

LANGER 2007

LIVERANI 1995

LUCAS 1900

MATZ-DuHN III

MenEGHini 2009

Milella 2007

OSTROWSKI 1900

ÖSTENBERG 2009

PAIS 1979

PAPI 2005

PARISI PRESICCE 1999

PARISI PRESICCE 2005

RIC II

RIC III

SALCEDO 1996

SAPELLI 1999

SCHMIDT-DICK 2011

SEELENTAG 2004
= J. ARCE: La iconografía de „Hispania” en época romana. AEA 53 (1980) 77-102.

= P. BIEŃKOWSKI: De simulacris barbarum gentium apud romanos. Kraków 1900.

= A. R. BIRLEY: Hadrian. The Restless Emperor. New York 1997.

= M. T. Boatwright: Antonine Rome. Security in the homeland. In: The Emperor and Rome. Space, representation and ritual. Eds: B.C. Ewald, C. F. Noreña. Cambridge 2010, 169-198.

= E. Christof: Das Glück der Stadt: die Tyche von Antiochia und andere Stadttychen. Europäische Hochschulschriften 74. Frankfurt a. M.-New York 2001.

= A. CLARIDGE: L'Hadrianeum in Campo Marzio. Storia dei rinventimenti e topografia antica nell'area di piazza di Pietra. In: Provinciae fideles. Il fregio del tempio di Adriano in Campo Marzio. Ed.: M. Sapelli. Milano 1999, 117-127.

= E. DODERO: Catalogo nr. 13-15. In: Le sculture Farnese. III.: Le sculture delle terme di Caracalla. Rilievi e varia. Ed.: C. Gasparri. Napoli 2010, 60-68.

= I. Domes: Darstellung der Africa. Typologie und Ikonographie einer römischen Provinzpersonifikation. IntArch 100. Rahden 2007.

= F. FLESS: Griechen - Skythen - Bosporaner. In: Griechen, Skythen, Amazonen. Hrsg.: U. Kästner, M. Langer, B. Rabe. Berlin 2007, 53-54.

= C. Franzoni-A. Tempesta: Il Museo di Francesco Gualdi nella Roma del Seicento tra raccolta privata ed esibizione pubblica. BdA 73 (1992) 1-42.

= N. HANNESTAD: Roman Art and Imperial Policy. Aarhus 1988.

= W. Helbig: Führer durch die öffentlichen Sammlungen klassischer Altertümer in Rom II. Tübingen 1969. 4. Auflage.

= L. R. Houghtalin: The Personifications of the Roman Provinces. Ann Arbor 1966.

= M. JATTA: Le rappresentanze figurate delle provincie romane. Roma 1908.

= M. LANGER: Fremdheit im Mythos. In: Griechen, Skythen, Amazonen. Hrsg.: U. Kästner, M. Langer, B. Rabe. Berlin 2007, 31-34.

= P. LIVERANI: 'Nationes' e 'civitates' nella propaganda imperial. RM 102 (1995) 219-249.

= H. LuCAS: Die Reliefs der Neptunsbasilica in Rom. JdI 15 (1900) 1-42.

= F. MATZ-F. K. v. DuHn: Antike Bildwerke in Rom III. Leipzig 1882.

= R. MENEGHINI: I Fori imperiali e i Mercati di Traiano. Roma 2009.

= M. Milella: Il Foro di Traiano. In: Il Museo dei Fori Imperiali nei Mercati di Traiano. Ed.: L. Ungaro. Milano 2007, 197-211.

= J. A. OstrowsKi: Les personnifications des provinces dans l'art romain. Warszawa 1990.

= I. ÖstenberG: Staging the World: spoils, captives, and representations in the Roman triumphal procession. Oxford 2009.

= A. M. PAIs: Il "podium” del tempio del Divo Adriano a Piazza di Pietra in Roma. Roma 1979.

= C. PAPI: The age of the Antonines. In: Hadrianeum. Ed.: R. Novelli. Roma, 2005, 52-70.

= C. PARISI PRESICCE: Le rappresentazioni allegoriche di popoli e province nell'arte romana imperiale. In: Provinciae fideles. Il fregio del tempio di Adriano in Campo Marzio. Ed.: M. Sapelli. Milano 1999, 83-105.

= C. PARISI Presicce: The enclosure of the Hadrianeum. In: Hadrianeum. Ed.: R. Novelli. Roma 2005, 76-108.

= H. Mattingly-E. A. Sydenham: The Roman Imperial Coinage. II. London 1926.

= H. Mattingly-E. A. Sydenham: The Roman Imperial Coinage. III. London 1930.

= F. SALCEDO: Africa. Iconografía de una provincia romana. Bibliotheca Italica 21. Roma 1996.

= M. SAPELLI: Provinciae fideles. Il fregio del tempio di Adriano in Campo Marzio. Milano 1999.

= F. SCHMIDT-Dick: Typenatlas der römischen Reichsprägung von Augustus bis Aemilianus II. Männliche Darstellungen. Veröffentlichungen der Numismatischen Kommission 55. Wien 2011.

= G. SeElentag: Taten und Tugenden Traians. HERMES Einzelschriften 91. Stuttgart 2004.

35 TOYNBEE 1934,157 ; PAPI 2005, 54-58. 
SMITH 1988

STRACK 1933

STRONG 1907

TOYNBEE 1934

TYRELL 1989

VITALE 2012

ZAHNRT 2007
$=$ R. R. R. SмITH: The Ethne from the Sebasteion at Aphrodisias. JRS 78 (1988) 50-77.

= P. STRACK: Untersuchungen zur römischen Reichsprägung des zweiten Jahrhunderts. II.: Die Reichsprägung zur Zeit des Hadrian. Stuttgart 1933.

$=$ E. StRong: Roman Sculpture from Augustus to Constantine. London 1907.

= J. M. C. ToynbeE: The Hadrianic School: A chapter in the history of Greek art. Cambridge 1934.

=W. B. Tyrell: Amazons. A study in Athenian mythmaking. Baltimore 1989.

= M. Vitale: Personifikationen von Provinciae auf den Münzprägungen unter Hadrian: Auf den ikonographischen Spuren von "Statthalterprovinzen” und “Teilprovinzen”. Klio 94 (2012) 156-174.

$=$ M. ZAHNRT: Hadrians „Provinzmünzen”. In: Herrschen und Verwalten. Der Alltag der römischen Administration in der Hohen Kaiserzeit. Hrsg.: R. Haensch. Köln 2007, 195-212. 